\title{
Receptor-mediated Phagocytosis in Human Neutrophils Is Associated with Increased Formation of Inositol Phosphates and Diacylglycerol

\author{
Elevation in Cytosolic Free Calcium and Formation of Inositol Phosphates Can Be Dissociated
} from Accumulation of Diacylglycerol
}

\author{
Maria Fällman, Daniel P. Lew, * Olle Stendahl, and Tommy Andersson \\ Department of Medical Microbiology, University of Linköping, S-581 85 Linköping, Sweden; and *Division of Infectious Diseases, \\ Department of Medicine, University Hospital, CH-1211 Geneva 4, Switzerland
}

\begin{abstract}
Phagocytosis of C3bi- or IgG-opsonized yeast particles in human neutrophils was found to be associated with an increased formation of inositol phosphates and diacylglycerol. Pertussis toxin only marginally affected phagocytosis of IgGand C3bi-opsonized particles and the associated formation of second messengers. Forskolin, which induced a threefold rise of cellular cAMP, however, markedly inhibited both $\mathrm{C} 3 \mathrm{bi}-$ and IgG-mediated phagocytosis as well as the particle-induced formation of inositol phosphates and diacylglycerol. These observations are in contrast to what was found to occur with chemotactic factors and indicate that chemotactic and phagocytic signaling can be regulated independently in human neutrophils.

Since C3bi-mediated phagocytosis has been shown to occur at vanishingly low cytosolic free calcium levels, calcium-depleted cells were used to study the importance of the inositol cycle for the engulfment of C3bi-opsonized particles. Despite a total lack of receptor-induced formation of inositol phosphates, a significantly increased accumulation of diacylglycerol accompanied the ingestion of $\mathrm{C} 3 \mathrm{bi}$-opsonized particles. These data show that the engulfment of $\mathrm{C} 3 \mathrm{bi}$-opsonized particles can occur independently of both a calcium transient and an increased inositol phosphate production. However, the observed accumulation of diacylglycerol, not derived from phosphoinositides, suggests that this second messenger play a role in the control of the engulfment process.
\end{abstract}

\section{Introduction}

The phagocytic process in human neutrophils is triggered mainly by two different receptor-mediated mechanisms, one that recognizes the C3bi-fragment of the complement system and another that recognizes the Fc domain of immunoglobulin $G$ (1). The transduction mechanisms regulating the phagocytic process have so far only been partly elucidated. What is known is that receptor-mediated phagocytosis occurring via the two major opsonins is associated with a rise in the concentration of cytosolic free $\mathrm{Ca}^{2+}(2-4)$. Even more interesting are the observations that in human neutrophils only IgG-mediated ingestion is actually dependent on the rise of cytosolic

Address reprint requests to Dr. Fällman, Department of Cell Biology, University of Linköping, S-58185 Linköping, Sweden.

Received for publication 30 September 1987 and in revised form 12 April 1989.

J. Clin. Invest.

(c) The American Society for Clinical Investigation, Inc.

0021-9738/89/09/0886/06 \$2.00

Volume 84, September 1989, 886-891 free $\mathrm{Ca}^{2+}$, whereas the ingestion of $\mathrm{C} 3 \mathrm{bi}$-opsonized particles can occur in the absence of such a rise (3). These data extend the previous observation by Stossel et al. (5) that demonstrated that the ingestion of $\mathrm{C} 3 \mathrm{~b}$ endotoxin-coated oil droplets by neutrophils could occur in EDTA-containing medium. In addition, it has also been demonstrated that in macrophages (J774 cells) the rise in intracellular $\mathrm{Ca}^{2+}$ is not a requirement for the phagocytic uptake of IgG-opsonized particles (2). Consequently, it seems reasonable to propose the existence of at least one additional intracellular messenger participating in the regulation of receptor-mediated phagocytosis.

Receptor-mediated activation of phospholipase $C$, via a regulatory $G$ protein, and with the subsequent turnover of the inositol cycle, is a well-documented pathway in cellular signal transduction (for review see Berridge [6]). The hydrolysis of phosphatidyl 4,5-bisphosphate $\left[\operatorname{PtdIns}(4,5) \mathrm{P}_{2}\right]^{1}$ leads to an accumulation of two major second messengers, inositol $1,4,5$ trisphosphate $\left[\operatorname{Ins}(1,4,5) \mathrm{P}_{3}\right]$ and 1,2-diacylglycerol. The former induces the mobilization of intracellular calcium whereas the latter is the endogenous activator of protein kinase C. In human neutrophils, both $\mathrm{Ca}^{2+}$ and protein kinase $\mathrm{C}$ activity appear to be necessary for mediating secretion triggered by chemotactic factors such as FMLP and leukotriene $B_{4}$ $\left(\mathrm{LTB}_{4}\right)$ (7-9)

The aim of the present study was to investigate initially whether ingestion of IgG- or C3bi-opsonized yeast particles by human neutrophils is associated with an increased formation of inositol phosphates, as recently demonstrated in macrophages (10) and diacylglycerol, but more importantly, whether these second messengers play a role in the control of phagocytosis in these cells.

\section{Methods}

Materials. The materials and their sources were as follows: pertussis toxin (List Biological Laboratories Inc., Cambell, CA); forskolin (Calbiochem-Behring Corp., La Jolla, CA); myo- $\left[2-{ }^{3} \mathrm{H}\right]$ inositol, bis $(O$ aminophenoxyl)ethane- $N, N, N^{\prime}, N^{\prime}$-tetraacetic acid (quin2), tetraacetomethyl ester of quin2 (quin2-AM), $\left[\gamma-{ }^{32} \mathrm{P}\right] \mathrm{ATP}$, Hyperfilm multipurpose, and cAMP assay kit (Amersham International, Amersham, Bucks., UK); Dowex $1 \times 8$ (200-400 mesh), FMLP, cardiolipin, and diethylenetriaminepentaacetic acid (Sigma Chemical Co., St. Louis, MO); octylglycoside and imidazol (Boehringer Mannheim, Mannheim, Federal Republic of Germany); 1,2-diacylglycerol kinase purified from Escherichia coli (Lipidex, Inc., Middleton, WI); silica gel 60 thin-layer chromatography plates (Merck \& Co., Darmstadt, Federal

1. Abbreviations used in this paper: InsP, inositol monophosphate; Ins $P_{2}$, inositol bisphosphate; Ins $P_{3}$, inositol trisphosphate; Ins $(1,4,5) \mathrm{P}_{3}$, inositol 1,4,5-trisphosphate; quin2, bis(o-aminophenoxyl)ethane- $N, N, N^{\prime}, N^{\prime}$-tetraacetic acid; PtdIns $(4,5) \mathrm{P}_{2}$, phosphatidylinositol 4,5-bisphosphate; quin2-AM, tetraacetomethyl ester of quin2. 
Republic of Germany); dextran and Ficoll-Hypaque (Pharmacia Fine Chemicals, Uppsala, Sweden).

Preparation of human neutrophils. Blood from healthy volunteers was collected in heparin-containing tubes, and the neutrophils were isolated according to the method described by Böyum (11). In short, after elimination of erythrocytes by dextran sedimentation followed by a brief hypotonic lysis, the cell suspension was centrifuged on a FicollPaque gradient to separate the polymorphonuclear leukocytes from lymphocytes, monocytes, and platelets. The neutrophils were then washed twice before being suspended in a calcium containing medium: $138 \mathrm{mM} \mathrm{NaCl}, 6 \mathrm{mM} \mathrm{KCl}, 1 \mathrm{mM} \mathrm{MgSO}, 1.1 \mathrm{mM} \mathrm{CaCl}_{2}, 0.1 \mathrm{mM}$ EGTA, $1 \mathrm{mM} \mathrm{NaHPO}$, $5 \mathrm{mM} \mathrm{NaHCO}$, $5.5 \mathrm{mM}$ glucose, and 20 $\mathrm{mM}$ Hepes ( $\mathrm{pH}$ 7.4). In some experiments calcium and EGTA were excluded from the medium. Throughout this paper these media are referred as the "calcium-containing medium" and "calcium-free medium," respectively. Cellular counting of neutrophils was performed either in a Bürker chamber or with a model ZF counter with a 100channel pulse height analyzer from Coulter-Electronics, Ltd., Dunstable, UK.

Depletion of intracellular calcium. Depletion of intracellular calcium, to inhibit agonist-induced activation of phospholipase $C$, was carried out by incubating the neutrophils $\left(5 \times 10^{7}\right.$ cells $\left./ \mathrm{ml}\right)$ in calcium-free medium with $50 \mu \mathrm{M}$ quin2-AM and $1 \mathrm{mM}$ EGTA for $1 \mathrm{~h}$ at $37^{\circ} \mathrm{C}$ in a humidified atmosphere of $5 \% \mathrm{CO}_{2}(12)$. The subsequent exposure to $\mathrm{C} 3 \mathrm{bi}$-opsonized particles was performed in calcium-free medium supplemented with 1 mM EGTA.

Determination of cAMP content. Neutrophils $\left(10^{7}\right.$ cells $\left./ \mathrm{ml}\right)$ were incubated with forskolin $(100 \mu \mathrm{M})$ for various periods of time at $37^{\circ} \mathrm{C}$. The reactions were terminated by adding ice-cold ethanol (final concentration 65\%). The different samples were then allowed to settle for 1 $h$ in a freezer, after which the different supernatants containing cAMP were collected. The precipitated materials were washed with fresh $65 \%$ ice-cold ethanol to ensure that the extraction of cAMP was as complete as possible. The supernatants were then centrifuged at $2,000 \mathrm{~g}$ for 15 min at $4^{\circ} \mathrm{C}$, and the precipitates were discarded. The remaining supernatants were then evaporated under nitrogen, and the cAMP content was assayed with a commercial kit (Amersham International).

Determination of phagocytosis. Phagocytosis of FITC-labeled yeast particles was monitored by a fluorescence-quenching method $(3,13)$, in which the extracellular particles are quenched by adding trypan blue. The IgG-coated particles were opsonized by incubating yeast with purified anti-yeast IgG $(24 \mu \mathrm{g} / \mathrm{ml})$ in the presence of $20 \%$ heat-inactivated $\left(56^{\circ} \mathrm{C}, 30 \mathrm{~min}\right)$ human serum; C3bi-coated particles were opsonized by incubating the yeast with $20 \%$ fresh human serum. All particles were incubated at $37^{\circ} \mathrm{C}$ for $30 \mathrm{~min}$ and washed before use. Yeast particles were presented to neutrophils in a ratio of 5:1. Phagocytosis is calculated as the number of yeast particles ingested per 100 cells.

Determination of inositol phosphate formation. Phosphoinositides and inositol phosphates were labeled by incubating cells $\left(5 \times 10^{7} / \mathrm{ml}\right)$ with myo- $\left[2-{ }^{3} \mathrm{H}\right]$ inositol $(50 \mu \mathrm{Ci} / \mathrm{ml})$ in the previously described calcium-containing medium (except for a reduction of the $\mathrm{Ca}^{2+}$ concentration to $0.5 \mathrm{mM}$ ) or in calcium-free medium for $2 \mathrm{~h}$ in an atmosphere of $5.0 \% \mathrm{CO}_{2}$ at $37^{\circ} \mathrm{C}$. For the determination of particle-induced changes in the formation of inositol phosphates, the labeled cells were washed, resuspended, and put on ice. The cells were then mixed with a solution of either IgG- or C3bi-opsonized yeast particles $\left(4^{\circ} \mathrm{C}\right)$. The mixtures of cells and yeast particles were then put in a water bath $\left(37^{\circ} \mathrm{C}\right)$ for various periods of time (see illustrations). The phagocytic process was terminated by adding ice-cold trichloroacetic acid (final concentration $15 \%$, vol/vol). For extraction of the inositol phosphates, we used a previously described procedure $(7,9,14)$, i.e., samples were first put on ice for $15 \mathrm{~min}$ and then centrifuged. The supernatants thus obtained were washed three times with a fivefold excess of diethyl ether. The washed extracts were adjusted to $\mathrm{pH} 7.5$ with Tris (final concentration $0.2 \mathrm{M}$ ), and the inositol phosphates were separated, by stepwise elution, from small Dowex anion-exchange columns. After addition of $67 \%$ Aquasol, the radioactivity of the different fractions was determined by liquid-scintillation counting. In the present study no attempts were made to distinguish between the two isomers of $\mathrm{InsP}_{3}$ $(7,15)$.

Determination of 1,2-diacylglycerol formation. For determination of particle-induced changes in cellular diacylglycerol contents, neutrophils were washed and resuspended in the calcium-containing medium or calcium-free medium and put on ice. The cells were then mixed with a solution of either IgG- or C3bi-opsonized yeast particles $\left(4^{\circ} \mathrm{C}\right)$. The mixtures of cells and yeast particles were then put in a water bath $\left(37^{\circ} \mathrm{C}\right)$ for various periods of time (see illustrations). The phagocytic process was terminated by adding an ice-cold solution of chloroform/ methanol $(1: 2, \mathrm{vol} / \mathrm{vol})$, and cellular lipids were extracted according to the method developed by Bligh and Dyer (16). The assay used was essentially as previously described by others $(17,18)$. Each sample, which had been evaporated under nitrogen, was solubilized in $20 \mu \mathrm{l}$ of a mixture containing $5 \mathrm{mM}$ cardiolipin, $225 \mathrm{mM}$ octylglycoside, and 1 $\mathrm{mM}$ diethylenetriaminepentaacetic acid, and then sonicated for $15 \mathrm{~s}$ and left for an additional $10 \mathrm{~min}$ at room temperature. The samples containing the solubilized lipids were then mixed with $50 \mu \mathrm{l}$ of a reaction solution containing $100 \mathrm{mM}$ imidazol- $\mathrm{HCl}(\mathrm{pH} 6.6), 100 \mathrm{mM}$ $\mathrm{NaCl}, 25 \mathrm{mM} \mathrm{MgCl}$, and $2 \mathrm{mM}$ EGTA; $2 \mu \mathrm{l}$ of a solution containing $100 \mathrm{mM}$ dithiothreitol and $1 \mathrm{mM}$ diethylenetriaminepentaacetic acid; $13 \mu \mathrm{l}$ of distilled water; and $5 \mu \mathrm{l}$ of a 1,2-diacylglycerol kinase solution (final activity $0.02 \mathrm{U}$ ). The samples were then incubated for $5 \mathrm{~min}$ at $26^{\circ} \mathrm{C}$, after which the enzymatio reactions were initiated by the addi-

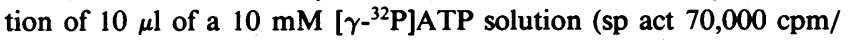
$\mathrm{nmol}$ ). After $15 \mathrm{~min}$ the reactions were stopped by adding $2 \mathrm{ml}$ of chloroform/methanol $(1: 2, \mathrm{vol} / \mathrm{vol})$ and the lipids were extracted as above. The samples were evaporated under nitrogen and resuspended in $30 \mu \mathrm{l}$ of chloroform before application on a silica gel 60 thin-layer chromatography plate. The plates were developed with chloroform/ methanol/acetic acid (65:15:5, vol/vol/vol), air-dried, and subjected to autoradiography. The spots corresponding to phosphatidic acid were scraped into scintillation vials, and, after adding $5 \mathrm{ml}$ of Aquasol to each vial, the radioactivity was determined in a scintillation counter (LKB Produkter, Bromma, Sweden).

\section{Results}

Phagocytosis of C3bi- and IgG-opsonized particles and formation of InsP $P_{3}$ and diacylglycerol. Ingestion of either C3bi- or IgG-opsonized particles (Fig. 1, $A$ and $D$ ), is associated with an increased accumulation of $\operatorname{InsP}_{3}$ (Fig. 1, $B$ and $E$ ). This increase precedes the formation of the less phosphorylated inositols, i.e., inositol monophosphate (InsP) and inositol bisphosphate $\left(\mathrm{InsP}_{2}\right)$ (data not shown). It could also be demonstrated that the ingestion of either C3bi- or IgG-opsonized yeast particles is associated with an increased accumulation of diacylglycerol, the natural activator of protein kinase $C$ (Fig. 1, C and $F$ ). This increase in cellular diacylglycerol content is much higher and more sustained than that observed after exposure to $\operatorname{FMLP}(17,19)$.

Effects of pertussis toxin on C3bi-and IgG-mediated phagocytosis and the associated formation of Ins $P_{3}$. Pertussis toxin $(200 \mathrm{ng} / \mathrm{ml})$ had only minor or no effects on phagocytosis of both C3bi- and IgG-opsonized particles and the associated formation of $\operatorname{InsP}_{3}$ (Table I). The toxin also lacked effect on particle-induced formation of diacylglycerol (data not shown). In comparison with the effects of pertussis toxin on the generation of intracellular signals as well as on several functional responses triggered by chemotactic factors $(7,9$, 20 ), its effects on phagocytosis and the associated formation of second messengers, shown in the present study, were minute. Not even if the dose of pertussis toxin was raised to $1.2 \mu \mathrm{g} / \mathrm{ml}$ $\left(2 \mathrm{~h}\right.$ at $37^{\circ} \mathrm{C}$ ) were the effects anything but minor (data not shown). 


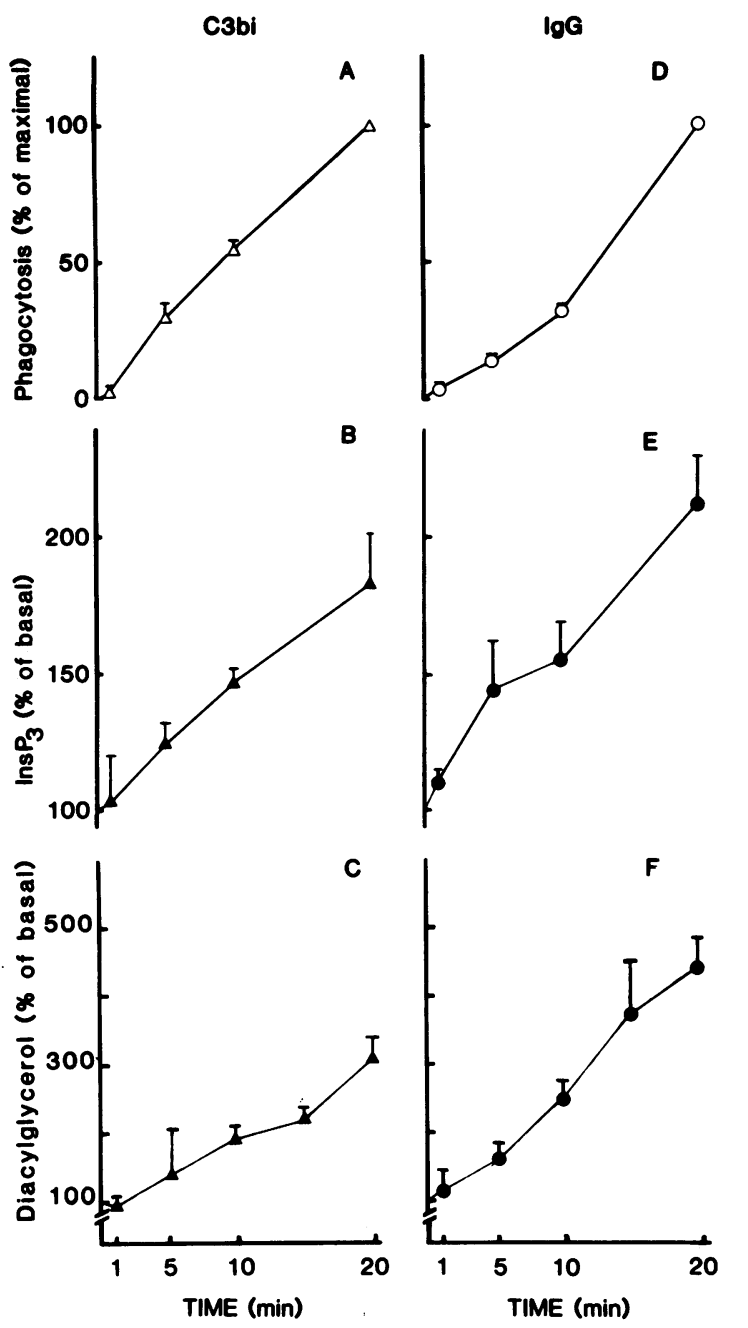

Figure 1. Human neutrophils were incubated with opsonized yeast particles at $37^{\circ} \mathrm{C}$ for various periods of time before the number of phagocytosed particles were counted or the contents of inositol phosphates or diacylglycerol were determined. $(A-C)$ Results obtained using C3bi-opsonized yeast particles; $(D-F)$ results obtained with IgG-opsonized yeast particles. The values given are mean \pm SEM of four to six separate experiments. The $100 \%$ level for C3bi- and IgGphagocytosis was $230 \pm 20$ and $256 \pm 16$ ingested yeast particles per 100 cells, respectively. The basal level for $\operatorname{InsP}_{3}$, i.e., $100 \%$, was $233 \pm 18 \mathrm{dpm}$. The amount of diacylglycerol in unstimulated cells was $241 \pm 20 \mathrm{pmol} / 10^{7}$ cells. Statistically significant changes in reference to time zero values, i.e., $100 \%$, were evaluated using Student's $t$ test for paired samples.

Effects of forskolin on C3bi- and IgG-mediated phagocytosis and the associated formation of InsP $\mathrm{P}_{3}$ and diacylglycerol. Purified neutrophils were preincubated with forskolin (100 $\mu \mathrm{M})$, an agent which, by activating adenylate cyclase, raises the cellular level of cAMP (21). In our experiments forskolin induced a threefold increase $(312 \%$ of controls, mean of three experiments) in cellular cAMP level after $10 \mathrm{~min}$. In the presence of forskolin, this elevated level remained for an additional $40 \mathrm{~min}$. The forskolin-induced rise in cAMP correlated with the decreased phagocytosis of both C3bi- and IgG-opsonized particles $(65 \pm 4 \%$ for IgG and $60 \pm 5 \%$ for C3bi, Fig. 2, dashed lines). The inhibition of receptor-mediated phagocytosis was associated with a corresponding reduction in the formation of
Table I. Effects of Pertussis Toxin on Phagocytic Capacity and InsP $P_{3}$ Formation in Human Neutrophils

\begin{tabular}{lll}
\hline & \multicolumn{1}{c}{ Phagocytosis } & \multicolumn{1}{c}{ InsP $_{3}$} \\
\hline \multicolumn{3}{c}{$\%$ of control } \\
C3bi yeast & $75 \pm 11^{*}(n=10)$ & $83 \pm 4 \quad(n=5)$ \\
IgG yeast & $67 \pm 13^{*}(n=10)$ & $74 \pm 5^{*}(n=5)$
\end{tabular}

Purified human neutrophils were preincubated with pertussis toxin $(200 \mathrm{ng} / \mathrm{ml})$ for $2 \mathrm{~h}$ at $37^{\circ} \mathrm{C}$ under a humidified atmosphere of $5.0 \%$ $\mathrm{CO}_{2}$. In these cells this batch of pertussis toxin blocked completely any FMLP-induced response. In experiments determining the formation of InsP $\mathrm{P}_{3}$ the medium was supplemented with $50 \mu \mathrm{Ci}$ of myo- $\left[{ }^{3} \mathrm{H}\right]$ inositol $/ \mathrm{ml}$. After the cells were washed, they were incubated with opsonized yeast particles for $20 \mathrm{~min}$ at $37^{\circ} \mathrm{C}$, and the number of phagocytosed particles were then counted and/or InsP content was determined. The pertussis toxin-induced changes in phagocytic capacity and $\mathrm{InsP}_{3}$ formation are given as percent of control. The values given are mean \pm SEM for four to seven experiments. The $100 \%$ level for C3bi and IgG phagocytosis were $231 \pm 45$ and $256 \pm 60$ ingested yeast particles per 100 cells, respectively. The basal level for InsP $P_{3}$, i.e., $100 \%$, was $365 \pm 86 \mathrm{dpm}$. Statistical analyses were done using Student's $t$ test for paired samples comparing pertussis toxin-treated cells with nontreated cells (i.e., cells preincubated with buffer for the same period of time) for the number of experiments given within parentheses. ${ }^{*} P<0.05$.

InsP $\mathrm{P}_{3}$ and diacylglycerol (Fig. 2). In contrast, similar treatment with forskolin had no effect on the FMLP-induced formation of InsP $\mathrm{P}_{3}$ (data not shown).

Effects of calcium-depletion on C3bi-mediated phagocytosis and the associated formation of diacylglycerol and inositol phosphates. Neutrophils were loaded with $50 \mu \mathrm{M}$ quin2 in a calcium-depleted medium $\left(\left[\mathrm{Ca}^{2+}\right] \sim 10^{-9} \mathrm{M}\right)$ to depress the cytosolic free $\mathrm{Ca}^{2+}$ level. In six separate experiments this treatment lowered the cytosolic free $\mathrm{Ca}^{2+}$ level to $40 \mathrm{nM}$ or less; this
C3bi

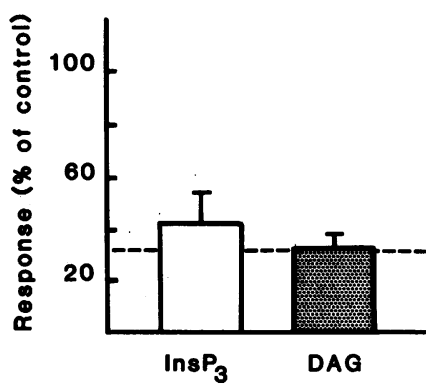

$\lg G$

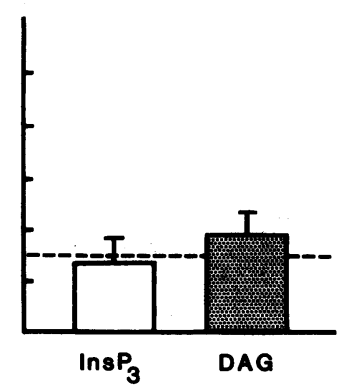

Figure 2. Purified human neutrophils were preincubated with forskolin $(100 \mu \mathrm{M})$ for $30 \mathrm{~min}$ before stimulation with opsonized yeast particles $(20 \mathrm{~min})$. Control cells were treated similarly but without forskolin. After these incubations the number of phagocytosed particles were counted or cellular contents of InsP $\mathrm{P}_{3}$ or diacylglycerol (DAG) were determined. (Dashed line) Effect of forskolin on phagocytosis. The values given are mean \pm SEM of five to eight separate experiments. The $100 \%$ level for C3bi and IgG phagocytosis was $233 \pm 31$ and $208 \pm 27$ ingested yeast particles per 100 cells, respectively. The basal level for InsP $\mathrm{P}_{3}$, i.e., $100 \%$, was $236 \pm 28 \mathrm{dpm}$. The amount of diacylglycerol in unstimulated cells was $174 \pm 30 \mathrm{pmol} / 10^{7}$ cells. Statistically significant changes produced by forskolin were tested using Student's $t$ test for paired samples. 
level is far below the $K_{d}$ of known $\mathrm{Ca}^{2+}$-binding proteins (22). Addition of ionomycin ( $500 \mathrm{nM})$ or C3bi-opsonized particles to these cells did not affect their cytosolic free $\mathrm{Ca}^{2+}$ level, as long as these cells were maintained in a $\mathrm{Ca}^{2+}$-depleted medium. This excludes the possibility of any rise in the cytosolic free calcium level occurring during these experimental conditions (data not shown). Compared with control cells, the calcium-depleted cells retained the major part of their phagocytic capacity for $\mathrm{C} 3$ bi-particles (Fig. $3 \mathrm{~A}$ ). In experiments performed in $\mathrm{Ca}^{2+}$-depleted medium with cells not loaded with quin 2 , it could be shown that $81 \%$ of this reduction (mean of three separate experiments) is due to the lack of extracellular calcium, which is known to result in a decreased association between yeast particles and cells. In calcium-depleted cells, as in control cells, the phagocytosis of $\mathrm{C} 3$ bi-opsonized particles was associated with a time-dependent accumulation of diacylglycerol (Fig. $3 \mathrm{~B}$ ). The kinetics of diacylglycerol formation in calcium-depleted cells is largely unaffected during the initial 5 min of the phagocytic period, but after this time accumulation becomes slower. However, despite a substantial uptake of C3bi-particles and formation of diacylglycerol, no formation of Ins $\mathrm{P}_{3}$ could be detected (Fig. 3 , inset). Neither was the Ins $\mathrm{P}_{2}$ and InsP fractions affected, which would have been the case if an early and transient hydrolysis of PtdIns(4,5) $\mathrm{P}_{2}$ had occurred. This agrees well with previously published data demonstrating that the activity of phospholipase $\mathrm{C}$ in intact cells is not regulated by $\mathrm{Ca}^{2+}$ but is instead dependent on a certain minimum concentration of this cation (23-25).

\section{Discussion}

In analogy with what is known about receptors for chemotactic factors, the present investigation shows that activation of $\mathrm{C} 3 \mathrm{bi}$ and IgG receptors on human neutrophils also results in an increased formation of Ins $\mathrm{P}_{3}$ and diacylglycerol, the two major second messengers in cellular transduction signaling. However, there are important differences between the chemotactic factor-induced and the phagocytosis-associated (C3bi or $\mathrm{IgG}$ ) formation of these second messengers. First, the amount of diacylglycerol formed in association with C3bi- and IgGmediated phagocytosis is much higher (present study) than the amount produced upon FMLP-induced stimulation of human neutrophils (own results and references 17 and 19). Secondly, C3bi- and IgG-mediated formation of second messengers was only slightly affected by pertussis toxin at a concentration that totally abolished signaling and functions elicited by chemotactic factors. Even at a sixfold higher toxin concentration, phagocytosis and the associated generation of second messengers were largely unaffected. This agrees well with a previous study (although that study dealt with a different kind of particle and much higher concentrations of pertussis toxin), which failed to demonstrate that pertussis toxin had any effect at all on receptor-mediated phagocytosis (26). In contrast, both chemotactic and secretory functions elicited by chemoattractants such as FMLP, C5a, and $\mathrm{LTB}_{4}$ are entirely suppressed by pertussis toxin. It is presently clear that there is a large variety of regulatory $\mathrm{G}$ proteins coupled to phospholipase $\mathrm{C}$, some of which are sensitive to ADP-ribosylation by pertussis toxin and some that are not (27-29). However, even when dealing with the 41-kD pertussis toxin-sensitive $G$ protein in neutrophils, it is not possible to obtain a complete ribosylation of this protein with the toxin. It has been shown by different investigators, using the same method as in the present study, that incubations with $100-2,000 \mathrm{ng} / \mathrm{ml}$ of pertussis toxin result in $63-89 \%$ ADP-ribosylation of the $41-\mathrm{kD}$ protein $(20,30,31)$. There are three alternative explanations for the observed differences in sensitivity to pertussis toxin between chemotactic factors and opsonins: phagocytosis requires $(a)$ no $\mathrm{G}$ protein or $(b)$ perhaps more likely, much less active $\mathrm{G}$ protein than chemotaxis; or $(c)$ the phagocytic process engages a $G$ protein insensitive to pertussis toxin and thus distinct from the protein participating in transduction signaling induced by chemotactic factors. Thirdly, the present study indicates a difference in sensitivity to high levels of cAMP between the transduction mechanism of particulate stimuli (C3bi and IgG) and that of chemotactic stimuli (own results and reference 32). Although we cannot exclude other mechanisms for the action of the forskolin-induced rise in CAMP, various studies have indicated that phos-

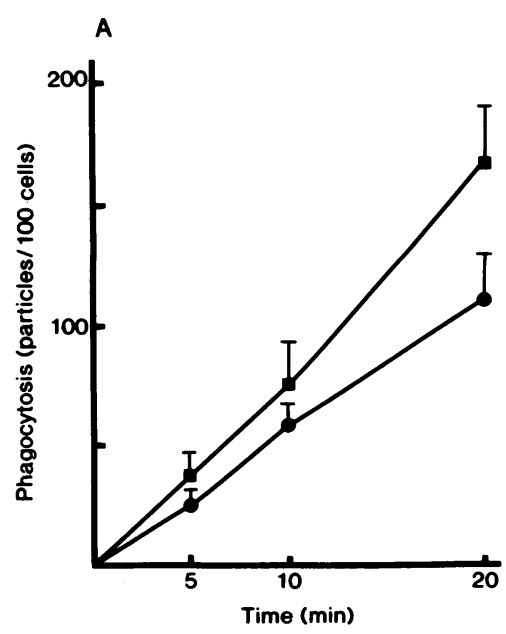

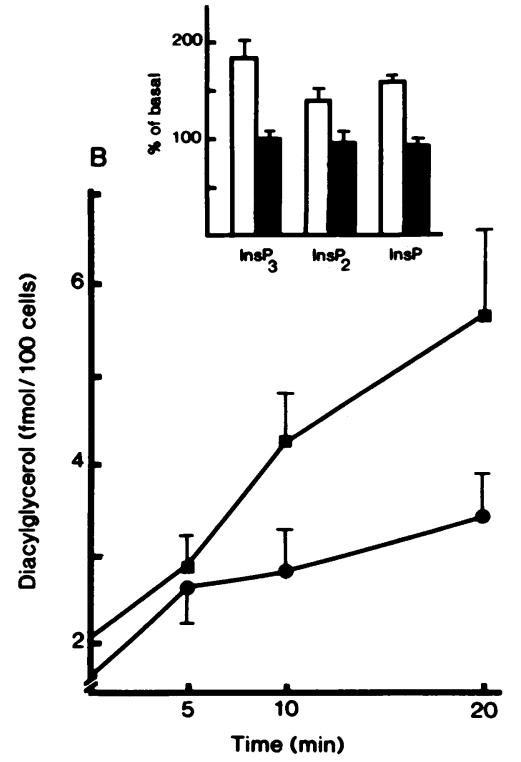

Figure 3. Human neutrophils were incubated with $50 \mu \mathrm{M}$ quin2-AM in calcium-free medium supplemented with $1 \mathrm{mM}$ EGTA $\left(\left[\mathrm{Ca}^{2+}\right] \sim 10^{-9}\right)$ at $37^{\circ} \mathrm{C}$ and in an atmosphere of $5.0 \% \mathrm{CO}_{2}$ for 60 min. Thereafter $\mathrm{C} 3 \mathrm{bi}$-opsonized particles were added. $(A)$ Time-dependent ingestion of C3bi particles for $(\boldsymbol{\omega})$ normal, nondepleted cells and $(\bullet)$ calcium-depleted cells. (B) C3bi-induced accumulation of diacylglycerol in ( $\square$ ) normal, nondepleted cells $(\square)$ and $(\bullet)$ calcium-depleted cells. The basal levels of diacylglycerol were $2.1 \pm 0.3 \mathrm{fmol}$ per 100 cells in nondepleted cells and $1.6 \pm 0.3 \mathrm{fmol}$ per 100 cells in calcium-depleted cells; these values were stable for at least $20 \mathrm{~min}$. (Inset) Relative effects of C3bi-opsonized particles on the accumulation of inositol phosphates after $20 \mathrm{~min}$ in nondepleted cells (open bars) and calcium-depleted cells (solid bars). The values given are means \pm SEM of four to nine experiments. 
pholipase $\mathrm{C}$, as well as other enzymes involved in the resynthesis of phosphoinositides, may be possible targets for cAMP $(32,33)$.

The abilities of human neutrophils to move and to engulf foreign organisms by phagocytosis are vital for their role in host defense. For optimal efficiency, it seems reasonable to postulate that human neutrophils are able to perform these two processes simultaneously and independently. This is initially accomplished by specific receptors for chemotaxis and phagocytosis. In addition, the present observations indicate that the transduction mechanisms coupled to these separate receptors can, on at least two different levels, be regulated independently of one another.

The phagocytic process is dependent on a well-functioning microfilamentous system, with actin as a major constituent (34). We have, as have others, previously excluded the possibility of a rise in cytosolic free $\mathrm{Ca}^{2+}$ or activation of protein kinase $C$ playing a major role in ligand-induced actin polymerization in human neutrophils $(35,36)$. However, these findings do not contradict the suggestion that some metabolite in the inositol cycle is directly involved in the regulation of cellular actin (37, 38). In the present study, by using $\mathrm{Ca}^{2+}$-depleted cells, it was demonstrated that the engulfment of $\mathrm{C} 3 \mathrm{bi}$-particles can occur independently of both calcium and increased production of inositol phosphates. This is in agreement with a recent report demonstrating that FMLP-induced polymerization of actin can occur in $\mathrm{Ca}^{2+}$-depleted cells independently of increased hydrolysis of PtdIns(4,5) $\mathrm{P}_{2}$ in human neutrophils (12). It should be pointed out that a decreased hydrolysis of PtdIns $(4,5) \mathrm{P}_{2}$ could result in a net increase in the amount of this phospholipid, in particular if there is a simultaneous activation of the phosphatidylinositol-4-phosphate kinase. Consequently, our data do not exclude the possibility that a net accumulation of PtdIns $(4,5) \mathrm{P}_{2}$ is the signal leading to polymerization of actin.

The observations that the engulfment process is associated with, but not dependent on, both an increased turnover of phosphoinositides and a subsequent rise of cytosolic free $\mathrm{Ca}^{2+}$, might appear contradictory. However, it must be kept in mind that during phagocytosis the uptake of particles is directly followed by other cellular events, such as fusion with primary and secondary granules as well as activation of the respiratory burst, processes that might well be dependent on the inositol cycle and/or a rise in cytosolic free calcium. This idea is supported by experiments showing that in human neutrophils the fusion between different granules and the plasma membrane is indeed $\mathrm{Ca}^{2+}$-dependent (39). In fact, we have recently been able to show that the fusion between phagosomes and granules, following ingestion, is a calcium-dependent process in human neutrophils (Stendahl et al., unpublished data).

Despite inhibition of phospholipase $\mathrm{C}$ activity, the ingestion of C3bi-opsonized particles was still associated with a significantly increased accumulation of diacylglycerol, the endogenous activator of protein kinase $C$. As could be expected, the accumulation of diacylglycerol was reduced as a consequence of the inhibition of $\mathrm{C} 3 \mathrm{bi}$-induced breakdown of PtdIns $(4,5) P_{2}$. The data clearly indicate the existence of at least one additional source for the generation of diacylglycerol. We do not know the identity of the precursor(s) participating in diacylglycerol formation during C3bi-mediated phagocytosis, however, it has been shown in human neutrophils, as well as in other cell types, that diacylglycerol accumulation can result from agonist-induced breakdown of phosphatidylcholine (40-43). Because of the observed generation of diacylglycerol, concomitant with phagocytosis under conditions in which $\mathrm{Ca}^{2+}$ does not play a role, protein kinase $\mathrm{C}$ activity appears to be a potential signal for the engulfment process in human neutrophils. In fact, the inhibition of both IgG- and C3b-mediated phagocytosis by forskolin can be reversed by addition of a direct activator of protein kinase $C$ (phorbol 12-myristate 13-acetate or 1-oleoyl 2-acetyl glycerol) (44). However, it is possible that diacylglycerol not generated from phosphoinositides can have as yet uncharacterized signaling effects, other than activation of protein kinase $C$, in receptormediated phagocytosis.

\section{Acknowledgments}

The authors are much indebted to Ms. Patricia Ödman for linguistic revision of the manuscript. This work was supported by grants from the Swedish Cancer Association, the Swedish MRC (grants 6956 and 5968), the Fonds National de la Recherche Scientifique Suisse (grant 3.829.0.87), The King Gustav V Memorial Foundation, the Swedish Rheumatic Association, the Siv Olsson Cancer Foundation, and the Nordic Insulin Foundation.

\section{References}

1. Silverstein, S. C., R. M. Steinman, and Z. A. Cohn. 1977. Endocytosis. Annu. Rev. Biochem. 46:669-721.

2. Di Virgilio, F., T. H. Steinberg, J. A. Swanson, and S. C. Silverstein. 1988. Fc receptor-mediated phagocytosis occurs in macrophages at exceedingly low $\mathrm{Ca}^{2+}$ levels. J. Cell Biol. 106:657-666.

3. Lew, D. P., T. Andersson, J. Hed, F. Di Virgilio, T. Pozzan, and O. Stendahl. 1985. $\mathrm{Ca}^{2+}$-dependent and $\mathrm{Ca}^{2+}$-independent phagocytosis in human neutrophils. Nature (Lond.). 315:509-511.

4. Young, L. D.-E., S. S. Ko, and Z. A. Cohn. 1984. The increase in intracellular free calcium associated with $\operatorname{IgG} \gamma 2 \mathrm{~b} / \gamma 1 \mathrm{Fc}$ receptor-ligand interactions: role in phagocytosis. Proc. Natl. Acad. Sci. USA. 81:5430-5434.

5. Stossel, T. P. 1973. Quantitative studies of phagocytosis: kinetic effects of cations and heat-labile opsonins. J. Cell Biol. 58:346-356.

6. Berridge, M. 1987. Inositol trisphosphate and diacylglycerol: two interacting second messengers. Annu. Rev. Biochem. 56:159-193.

7. Andersson, T., W. Schlegel, A. Monod, K.-H. Krause, O. Stendahl, and D. P. Lew. 1986. Leukotriene $B_{4}$ stimulation of phagocytes results in the formation inositol 1,4,5-trisphosphate. Biochem. J. 240:333-340.

8. Cockcroft, S. 1986. Phosphoinositides and neutrophil activation. In Phosphoinositide and Receptor Mechanisms. J. W. Putney, Jr., editor. Alan R. Liss, Inc., New York. 287-310.

9. Krause, K.-H., W. Schlegel, C. B. Wollheim, T. Andersson, F. A. Waldvogel, and D. P. Lew. 1985. Chemotactic peptide activation of human neutrophils and HL 60 cells: pertussis toxin reveals correlation between inositol trisphosphate generation, $\mathrm{Ca}^{2+}$ transients and cellular activation. J. Clin. Invest. 76:1348-1354.

10. Moscat, J., C. Herrero, P. Garcia-Barreno, and A. M. Municio. 1987. Zymosan-induced release of inositol phosphates at resting cytosolic $\mathrm{Ca}^{2+}$ concentrations in macrophages. Biochem. J. 242:441-445.

11. Böyum, A. 1968. Isolation of mononuclear cells and granulocytes from human blood. Scand. J. Clin. Lab. Invest. 97:77-89.

12. Bengtsson, T., I. Rundquist, O. Stendahl, M. P. Wymann, and T. Andersson. 1988. Increased breakdown of phosphatidylinositol 4,5-bisphosphate is not an initiating factor for actin assembly in human neutrophils. J. Biol. Chem. 263:17385-17389.

13. Hed, J., and O. Stendahl. 1982. Differences in the ingestion mechanisms of IgG and C3b particles in phagocytosis by human neutrophils. Immunology. 45:727-736. 
14. Berridge, M. J., R. M. C. Dawson, C. P. Downes, J. P. Henslop, and R. F. Irvine. 1983. Changes in the levels of inositol phosphates after agonist-dependent hydrolysis of membrane phosphatidylinositol. Biochem. J. 212:473-482.

15. Irvine, R. F., A. J. Letcher, D. J. Lander, and C. P. Downes. 1984. Inositol trisphosphates in carbachol-stimulated rat paratoid glands. Biochem. J. 223:237-243.

16. Bligh, E. G., and W. J. Dyer. 1959. A rapid method of total lipid extraction and purification. Can. J. Biochem. Physiol. 37:911-917.

17. Honeycutt, P. J., and J. E. Niedel. 1986. Cytochalasin B enhancement of the diacylglycerol response in formyl peptide-stimulated neutrophils. J. Biol. Chem. 261:15900-15905.

18. Preiss, J., C. R. Loomin, W. R. Bishop, R. Stein, J. E. Niedel, and J. E. Bell. 1986. Quantitative measurements of $s n$-1,2-diacylglycerols present in platelets, hepatocytes, and ras- and sis-transformed normal rat kidney cells. J. Biol. Chem. 261:8597-8600.

19. Truett, A. P. III, M. W. Vergese, S. B. Dillon, and R. Snyderman. 1988. Calcium influx stimulates a second pathway for sustained diacylglycerol production in leucocytes activated by chemoattractants. Proc. Natl. Acad. Sci. USA. 85:1549-1553.

20. Bradford, P. G., and R. P. Rubin. 1985. Pertussis toxin inhibits chemotactic factor induced phospholipase $\mathrm{C}$ stimulation and lysosomal enzyme secretion. FEBS (Fed. Eur. Biochem. Soc.) Lett. 183:317-320.

21. Seamon, K. B., W. Padgett, and J. W. Daly. 1981. Forskolin: Unique diterpene activator of adenylate cyclase in membrane and in intact cells. Proc. Natl. Acad. Sci. USA. 78:3363-3367.

22. Di Virgilio, F., D. P. Lew, and T. Pozzan. 1984. Protein kinase $\mathrm{C}$ activation of physiological processes in human neutrophils at vanishingly small cytosolic $\mathrm{Ca}^{2+}$ levels. Nature (Lond.). 310:691-693.

23. Thomas, A. P., J. S. Marks, K. E. Coll, and J. R. Williamson. 1983. Quantitation of early kinetics of inositol lipid changes induced by vasopressin in isolated and cultured hepatocytes. J. Biol. Chem. 258:5716-5725.

24. Downes, P., and R. Michell. 1985. Inositol phospholipid breakdown as a receptor controlled generator of second messengers. In Molecular Mechanisms of Transmembrane Signalling. P. Cohen and M. D. Houslay, editors. Elsevier, Amsterdam. 3-56.

25. Cockcroft, S. 1986. The dependence on $\mathrm{Ca}^{2+}$ of the guanine nucleotide activated polyphosphoinositide phosphodiesterase in neutrophil plasma membranes. Biochem. J. 240:503-507.

26. Lad, P. M., C. V. Olson, and I. S. Grewal. 1986. A step sensitive to pertussis toxin and phorbol ester in human neutrophils regulates chemotaxis and capping but not phagocytosis. FEBS (Fed. Eur. Biochem. Soc.) Lett. 200:91-96.

27. Cockcroft, S. 1987. Polyphosphoinositide phosphodiesterase: regulation by a novel guanine nucleotide binding protein, $G_{p}$. Trends Biochem. Sci. 12:75-78.

28. Neer, E. J., and D. E. Clapham. 1988. Roles of G protein subunits in transmembrane signalling. Nature (Lond.). 333:129-134.

29. Uhing, R. J., V. Prpic, H. Jiang, and J. H. Exton. 1986. Hormone-stimulated polyphosphoinositide breakdown in rat liver plasma membranes. J. Biol. Chem. 261:2140-2146.
30. Okajima, F., T. Katada, and M. Ui. 1985. Coupling of the guanine nucleotide regulatory protein to chemotactic peptide receptors in neutrophil membranes and its uncoupling by islet-activating protein, pertussis toxin. J. Biol. Chem. 260:6761-6768.

31. Feister, A. J., B. Browder, H. E. Willis, T. Mohanakumar, and S. Ruddy. 1988. Pertussis toxin inhibits human neutrophil responses mediated by the 42-kilodalton IgG Fc receptor. J. Immunol. 141:228233.

32. Della Bianca, V., P. De Togni, M. Grzeskowiak, L. M. Vicentini, and F. Di Virgilio. 1986. Cyclic AMP inhibition of phosphoinositide turnover in human neutrophils. Biochim. Biophys. Acta. 886:441-447.

33. Watson, S. P., R. T. McConnell, and E. G. Lapetina. 1984. The rapid formation of inositol phosphates in human platelets by trombin is inhibited by prostacyclin. J. Biol. Chem. 256:13199-13203.

34. Sheterline, P., J. E. Rickard, and R. C. Richards. 1984. Fc receptor-directed phagocytic stimuli induce transient actin assembly at an early stage of phagocytosis in neutrophils. Eur. J. Cell Biol. 34:8087.

35. Bengtsson, T., O. Stendahl, and T. Andersson. 1986. The role of the cytosolic free $\mathrm{Ca}^{2+}$ transient for $\mathrm{Pet}-\mathrm{Leu}-\mathrm{Phe}$ induced actin polymerization in human neutrophils. Eur. J. Cell Biol. 42:338-343.

36. Sklar, L. A., G. M. Omann, and R. G. Painter. 1985. Relationship of actin polymerization and depolymerization to light scattering in human neutrophils: dependence of receptor occupancy and intracellular $\mathrm{Ca}^{2+}$. J. Cell Biol. 101:1161-1166.

37. Janmey, P. A., and T. P. Stossel. 1987. Modulation of gelsolin function by phosphatidylinositol 4,5-bisphosphate. Nature (Lond.). 325:362-364.

38. Lassing, I., and U. Lindberg. 1985. Specific interaction between phosphatidylinositol 4,5-bisphosphate and profilactin. Nature (Lond.). 314:472-474.

39. Lew, D. P., A. Monod, F. A. Waldvogel, B. Dewald, M. Baggiolino, and T. Pozzan. 1986. Quantitative analysis of the cytosolic free calcium dependency of exocytosis from three subcellular compartments in intact human neutrophils. J. Cell Biol. 102:2197-2204.

40. Besterman, J. M., V. Durino, and P. Cuatrecasas. 1986. Rapid formation of diacylglycerol from phosphatidylcholine: a pathway for generation of a second messenger. Proc. Natl. Acad. Sci. USA. 83:6785-6789.

41. Daniel, L. W., M. Waite, and R. L. Wykle. 1986. A novel mechanism of diglyceride formation. J. Biol. Chem. 261:9128-9132.

42. Fällman, M., O. Stendahl, and T. Andersson. 1989. Phorbol ester-induced activation of protein kinase $C$ leads to increased formation of diacylglycerol in human neutrophils. Exp. Cell Res. 181:217225.

43. Glatz, J. A., J. G. Muir, and A. W. Murray. 1987. Direct evidence for phorbol ester-stimulated accumulation of diacylglycerol derived from phosphatidylcholine. Carcinogenesis. 8:1943-1945.

44. Andersson, T., M. Fällman, D. P. Lew, and O. Stendahl. 1988 Does protein kinase $\mathrm{C}$ control receptor-mediated phagocytosis in human neutrophils? FEBS (Fed. Eur. Biochem. Soc.) Lett. 239:371375. 